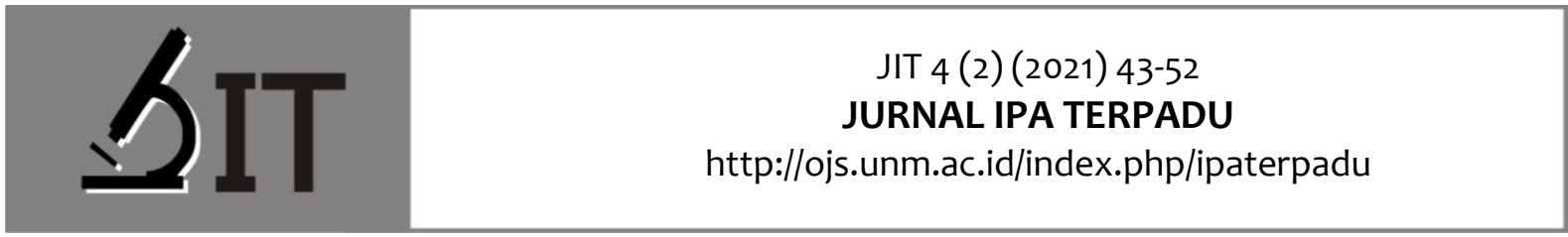

p-ISSN : 2597-8977

e-ISSN : 2597-8985

Elsa Octavia Sitohang *)

Universitas Pendidikan Ganesha

I Nyoman Suardana

Universitas Pendidikan Ganesha

Kompyang Selamet

Universitas Pendidikan Ganesha
*) Correspondence Author: elsaosit@gmail.com

\section{ANALISIS KONTRIBUSI KESIGAPAN BELAJAR DAN METODE BELAJAR SISWA SMP TERHADAP HASIL BELAJAR IPA PADA PEMBELAJARAN JARAK JAUH}

Abstrak: Penelitian ini bertujuan menganalisis kontribusi kesigapan belajar dan metode belajar siswa SMP terhadap hasil belajar IPA pada pembelajaran jarak jauh. Jenis penelitian adalah ex post facto yang bersifat korelasional. Populasi penelitian adalah seluruh siswa kelas IX SMP Negeri 2 Seririt Tahun Pelajaran 2020/2021 yang berjumlah 194 siswa. Sampel penelitian berjumlah 130 siswa yang diambil menggunakan teknik proportional random sampling. Data kesigapan belajar dan metode belajar dikumpulkan menggunakan metode kuesioner sedangkan data hasil belajar dikumpulkan dengan metode tes. Analisis data menggunakan analisis korelasi dan analisis regresi dengan taraf signifikansi 0,05. Hasil penelitian ini menunjukkan bahwa terdapat korelasi yang positif dan signifikan antara kesigapan belajar dan metode belajar secara simultan dengan hasil belajar IPA dengan angka signifikansi lebih kecil dari 0,05, koefisien korelasi sebesar 0,95 kategori sangat kuat, dan persamaan regresi yaitu $Y=29,040+0,246 X_{1}+0,698 X_{2}$. Kesigapan belajar dan metode belajar juga berkontribusi secara positif terhadap hasil belajar IPA dengan hasil sumbangan efektif (SE) kedua prediktor terhadap variabel kriterium yaitu sebesar $90,5 \%$.

Kata Kunci: Kesigapan Belajar, Metode Belajar, Hasil Belajar IPA.

Abstract: This study aims to analyze the contribution of delay avoidan and work methods of junior high school students to science learning outcomes in distance learning. This type of research is ex post facto which is correlational. The study population was a Seririt Public Junior High School 2 district 2020/2021 academic year for total 194 students. The research sample up to 130 students taken by proportional random sampling technique. Data of delay avoidan and work methods were collected by questionnaire method while data of science learning outcomes were collected by a test method. The analysis technique used to test the hypothesis was simple linear regression analysis and double regression analysis. The results of this study indicate that there is a positive and significant correlation between delay avoidan and work methods simultaneously with science learning outcomes with a significance number smaller than 0,05 , the correlation coefficient of 0,95 and the regression equation is $Y=29,040+0,246 X_{1}+0,698 X_{2}$. Delay avoidan and work methods also contributed positively to the science learning outcomes with the results of the effective contribution (SE) of the two predictors to the criterion variable, $90,5 \%$.

Keyword: Delay Avoidan, Work Methods, Science Learning Outcomes. 


\section{PENDAHULUAN}

Penyebaran wabah virus corona (COVID-19) telah ditetapkan sebagai pandemi oleh World Health Organization (WHO). Karena semakin mewabahnya virus COVID-19 ini, mengakibatkan perubahan dalam sistem kehidupan sosial termasuk metode pembelajaran di sekolah. Pembelajaran jarak jauh adalah salah satu cara untuk mengatasi penyebaran COVID-19, yaitu dengan menerapkan metode belajar dalam jaringan atau disingkat daring (online).

Narayana (2016) menyatakan bahwa penerapan pembelajaran jarak jauh ini menekankan pada penggunaan teknologi yang saat ini sedang berkembang, tentu tujuan utamanya adalah memudahkan guru dan siswa bertukar informasi dalam pembelajaran. Metode pembelajaran synchronous dan asynchronous menjadi metode yang banyak digunakan untuk memungkinkan siswa berinteraksi dengan lingkungan belajarnya. Pembelajaran synchronous artinya peserta didik dan pendidik terlibat dalam pembelajaran pada saat yang bersamaan saling bertukar informasi melalui media online tertentu seperti konferensi video melalui zoom atau google meet, live chat dan ceramah streaming langsung dari youtube. Sedangkan asynchronous artinya pembelajaran secara bebas, tidak terikat oleh waktu dan tempat dengan kata lain peserta didik mempelajari materi yang sama pada waktu dan lokasi yang berbeda tergantung pada waktu yang mereka pilih, contoh sebuah blog yang berisi postingan catatan pelajaran sekolah yang memberikan akses kepada siswa untuk memberikan komentar berupa pertanyaan pada hari yang ditentukan sendiri lalu pada hari tertentu akan dikomentari oleh siswa lain seperti forum diskusi. Pembelajaran jarak jauh dikatakan berhasil apabila semua tujuan pembelajaran yang telah ditetapkan dapat tercapai, seperti yang diungkapkan oleh Anni (dalam Widyantari, 2019) bahwa salah satu indikator tercapai atau tidaknya proses pembelajaran adalah dengan melihat hasil belajar yang dicapai siswa.

Sehubungan dengan peningkatan kualitas pembelajaran jarak jauh berbagai upaya telah dan tengah dilakukan oleh pemerintah diantaranya penerapan kurikulum darurat COVID-19. Kementerian Pendidikan dan Kebudayaan memberikan kemudahan bagi sekolah untuk menyederhanakan kurikulum sesuai kemampuan dan kebutuhan siswa. Hal tersebut terdapat dalam Keputusan Menteri Pendidikan dan Kebudayaan Republik Indonesia Nomor 719/P/2020 tentang Pedoman Pelaksanaan Kurikulum pada Satuan Pendidikan dalam kondisi khusus. Hal-hal terkait pelaksanaan kurikulum didukung oleh adanya Surat Edaran Sekretaris Jenderal No. 15 Tahun 2020 tentang Pedoman Pelaksanaan Belajar dari Rumah Selama Darurat Bencana COVID-19 di Indonesia. Surat edaran ini berisi tujuan, prinsip, metode dan media pelaksanaan belajar dari rumah, kemudian panduan pelaksanaan belajar dari rumah hingga panduan kegiatan pembelajaran saat satuan pendidikan kembali beroperasi.

Kenyataan di lapangan hasil belajar IPA siswa masih rendah, hal ini didukung oleh penelitian Napsawati (2020) yang menyatakan bahwa pada pelaksanaan pembelajaran jarak, siswa kesulitan memahami materi pelajaran IPA khususnya pada bagian perhitungan, tentu hal ini mengakibatkan hasil belajar siswa tidak optimal. Penelitian serupa oleh Sinaga et al., (2020) mengungkapkan bahwa pembelajaran jarak jauh yang telah dilaksanakan kurang efektif sehingga mempengaruhi hasil belajar siswa.

Kesenjangan yang terjadi antara upaya dan kenyataan disebabkan oleh berbagai faktor. Pencapaian hasil belajar siswa dalam pembelajaran dipengaruhi oleh faktor internal dan eksternal. Menurut Djaali (2009), faktor internal adalah faktor yang berasal dari diri sendiri meliputi minat, motivasi, kebiasaan, dan kecerdasan, sedangkan faktor eksternal adalah faktor yang berasal dari luar meliputi lingkungan seperti ruang kelas dan cara guru mengajar (Purwanto, 2004). Salah satu faktor internal yang mempengaruhi hasil belajar adalah kebiasaan belajar.

Berdasarkan penelitian tentang kebiasaan belajar, diantaranya hasil penelitian Rosyida et al., (2016) menunjukkan bahwa kebiasaan belajar sangat berpengaruh terhadap hasil belajar geografi siswa. Hal ini berarti bahwa semakin positif kebiasaan belajar siswa, maka hasil belajar geografi 
siswa semakin tinggi. Demikian pula sebaliknya, semakin negatif kebiasaan belajar siswa, maka hasil belajar geografi siswa akan semakin rendah.

Syah (2009), menyatakan bahwa kebiasaan belajar merupakan suatu proses pembentukan kebiasaan baru atau perbaikan kebiasaan yang sudah ada. Tujuan adanya kebiasaan belajar adalah memungkinkan siswa untuk menguasai sikap dan kebiasaan perilaku baru yang lebih tepat dalam arti selaras dengan kebutuhan ruang dan waktu. Diamati dari prosesnya, kebiasaan belajar memang lebih dominan pada tindakan siswa atau tingkah laku setiap kali melakukan proses pembelajaran secara konsisten, maksudnya apabila siswa memiliki kebiasaan belajar yang sudah baik dari dalam dirinya, maka secara langsung akan memberikan dampak pada diri siswa dalam menguasai materi pelajaran demi mencapai keberhasilan belajarnya di sekolah (Gie, 1995).

Kebiasaan belajar merupakan hal penting bagi siswa dalam proses belajar. Sudjana (2005) mengatakan keberhasilan siswa dalam belajar banyak bergantung pada kebiasaan belajar yang teratur dan berkesinambungan. Kebiasaan belajar memiliki pengaruh yang besar terhadap hasil belajar. Perbedaan kebiasaan belajar yang dimiliki menunjukkan perilaku belajar yang baik dan secara teratur dalam keseharian siswa. Pendapat lain dari Djaali (2009) menyatakan bahwa kebiasaan belajar merupakan metode atau teknik yang menetap pada diri siswa pada saat menerima pelajaran, membaca buku, mengerjakan tugas, dan mengatur waktu untuk menyelesaikan kegiatan. Djaali (2009) membagi kebiasaan belajar menjadi dua, yaitu delay avoidan dan work methods. Delay avoidan merupakan kebiasaan belajar seseorang yang berkaitan dengan ketepatan waktu dalam menyelesaikan tugas akademik, menghindari diri dari hal-hal yang memungkinkan tertundanya penyelesaian tugas, dan menghilangkan rangsangan yang akan mengganggu konsentrasi belajar. Delay avoidan dapat disebut kesigapan belajar. Sedangkan work methods adalah kebiasaan perilaku seseorang yang berkaitan dengan penggunaan cara (prosedur) pembelajaran yang efektif dan efisien dalam melaksanakan tugas akademik dan keterampilan belajar. Work methods dapat disebut metode belajar. Metode belajar digambarkan sebagai tingkah laku selama proses belajar yang berhubungan dengan prosedur belajar, keterampilan belajar dan strategi belajar yang digunakan. Prosedur belajar yang dimaksud merupakan usaha atau kegiatan yang dilakukan dalam mempelajari sesuatu. Kegiatan tersebut berupa pembelajaran di perpustakaan, cara membaca buku teks, cara cara mendapatkan bahan pelajaran, bertanya kepada guru atau kepada teman-teman yang dianggap lebih mampu. Keterampilan belajar yang dimaksudkan berkaitan dengan keunikan cara belajar yang dilakukan oleh siswa dan cara tersebut membuat siswa lebih cepat dalam mempelajari suatu materi. Kemampuan ini dapat terlihat pada saat mempelajari hal-hal tertentu, seperti kemampuan menghafal, mengulang pelajaran, dan membuat catatan untuk memudahkan mempelajari materi yang sulit. Kemudian, strategi belajar yang dimaksud berhubungan dengan metode yang digunakan untuk memperoleh hasil yang maksimal. Metode yang dimaksud adalah metode yang digunakan dalam mendekati suatu masalah, seperti menghadapi tugas dan menghadapi ujian. Menurut Sudjana (2005), ada beberapa hal yang perlu diperhatikan dalam proses pembelajaran yaitu (1) cara mengikuti pelajaran; (2) cara belajar mandiri di rumah; (3) cara belajar kelompok; (4) mempelajari buku teks; (5) menghadapi ujian. Cara yang dipakai itu akan menjadi kebiasaan. Hal ini juga didukung oleh Sudjana (2003) yang mengungkapkan bahwa kebiasaan belajar yang dapat berpengaruh terhadap hasil belajar meliputi: (1) pembuatan jadwal dan pelaksanaannya; (2) membaca dan membuat catatan; (3) mengulangi bahan pelajaran; (4) konsentrasi; dan (5) mengerjakan tugas.

Berdasarkan pendapat Djaali (2009), Sudjana (2005) dan Slameto (2003) yang telah digeneralisasikan, dimensi dan indikator yang digunakan dalam penelitian ini yaitu, pada kesigapan belajar meliputi (1) dimensi ketepatan waktu penyelesaian tugas, indikatornya mengumpulkan tugas tepat waktu; (2) dimensi konsentrasi belajar, indikatornya menghilangkan hal-hal yang mengganggu konsentrasi belajar. Sedangkan pada metode belajar meliputi (1) dimensi prosedur belajar, indikatornya cara mengikuti pelajaran, cara belajar kelompok dan cara belajar individu; (2) 
dimensi keterampilan belajar, indikatornya membaca dan membuat catatan, mengulang bahan pelajaran; dan (3) dimensi strategi belajar, indikatornya menghadapi ujian.

Temuan lain oleh Napsawati (2020) mengungkapkan bahwa hasil belajar siswa mengalami kemerosotan sejak diberlakukan pembelajaran jarak jauh akibat adanya pandemi COVID-19. Siswa cukup sulit memahami materi pembelajaran yang diajarkan secara online oleh karena itu kebiasaan belajar menjadi tantangan tersendiri bagi siswa.

Analisis pembelajaran menggunakan kebiasaan belajar yang pernah dilakukan sebelumnya terbatas pada hubungan kebiasaan belajar secara umum sehingga belum dijelaskan kontribusi kesigapan belajar dan metode belajar terhadap hasil belajar. Berdasarkan kajian konseptual dan hasil temuan yang telah diuraikan, perlu dilakukan penelitian lebih lanjut tentang kesigapan belajar dan metode belajar. Mengingat kesigapan belajar dan metode belajar merupakan bagian dari kebiasaan belajar yang bagi siswa sebagai faktor penting untuk mencapai hasil belajar yang baik, maka dilakukan penelitian lebih lanjut untuk mendapatkan data yang menunjukkan kontribusi kesigapan belajar dan metode belajar siswa SMP terhadap hasil belajar IPA pada pembelajaran jarak jauh.

\section{METODE}

Penelitian ini adalah ex post facto dengan jenis korelasional. Populasi penelitian adalah seluruh siswa kelas IX SMP Negeri 2 Seririt tahun pelajaran 2020/2021 yang berjumlah 194 siswa. Jumlah sampel yang digunakan sebanyak 130 siswa. Pengambilan sampel dilakukan dengan teknik proportional random sampling. Teknik proporsional random sampling digunakan untuk menentukan jumlah sampel dari setiap populasi secara proporsional (Sugiyono, 2019).

Instrumen yang digunakan dalam penelitian ini adalah kuesioner kesigapan belajar, kuesioner metode belajar dan tes hasil belajar IPA. Tes hasil belajar IPA berupa esai berjumlah 15 butir pertanyaan. Karakteristik tes ini adalah memiliki reliabilitas sebesar 0,79 dengan kualifikasi tinggi (Santyasa, 2014), valid dan memiliki daya pembeda lebih besar 0,20 dengan kualifikasi sedang (Candiasa, 2010), baik dan sangat baik serta memiliki tingkat kesukaran tes lebih besar dari 0,30 kualifikasi mudah, sedang, sukar (Candiasa, 2010).

Kuesioner kesigapan belajar yang telah diujicobakan pada siswa diperoleh sebanyak 18 butir pernyataan yang memenuhi kriteria sedangkan kuesioner metode belajar sebanyak 19 butir pernyataan yang memenuhi kriteria. Karakteristik kuesioner dalam penelitian ini adalah valid dan memiliki reliabilitas untuk kesigapan belajar sebesar 0,75 dan metode belajar sebesar 0,80 secara bersama-sama berkualifikasi tinggi (Santyasa, 2014).

Analisis data menggunakan analisis deskriptif dan inferensial. Analisis deskriptif digunakan untuk mendeskripsikan nilai rata-rata kesigapan belajar, metode belajar dan hasil belajar IPA. Nilai hasil belajar IPA siswa dikualifikasikan dengan Penilaian Acuan Patokan (PAP). Nilai kesigapan belajar dan metode belajar dikonversi ke skala seratus kemudian dikualifikasikan berdasarkan mean ideal (Mi) dan standar deviasi ideal (Sdi).

Analisis inferensial digunakan untuk menguji hipotesis. Uji hipotesis penelitian menggunakan analisis korelasi sederhana dan korelasi ganda serta regresi linier sederhana 1 prediktor dan regresi ganda 2 prediktor dengan taraf signifikansi 0,05. Sebelum pengujian hipotesis, dilakukan uji asumsi meliputi uji normalitas, linieritas dan keberartian arah regresi, uji multikolinieritas, uji autokorelasi dan uji heteroskedastisitas. 


\section{HASIL DAN PEMBAHASAN}

\section{Hasil}

Secara umum, hasil penelitian yang dideskripsikan yaitu nilai rata-rata kesigapan belajar, metode belajar, hasil belajar IPA, pengujian asumsi dan pengujian hipotesis. Perbandingan nilai ratarata kesigapan belajar, metode belajar dan hasil belajar IPA disajikan pada Tabel 1.

Tabel 1. Perbandingan nilai rata-rata kebiasaan belajar dan hasil belajar IPA

\begin{tabular}{cccc}
\hline Statistik & Kesigapan Belajar & Metode Belajar & Hasil Belajar IPA \\
\hline Mean & 65,43 & 65,52 & 58,70 \\
Standar Deviasi & 13,33 & 13,10 & 6,18 \\
Kategori & Baik & Baik & Sedang \\
\hline
\end{tabular}

Berdasarkan Tabel 1 perbandingan nilai rata-rata metode belajar tidak jauh berbeda dengan kesigapan belajar. Hal tersebut menunjukkan bahwa dibandingkan dengan kesigapan belajar, siswa dalam proses pembelajaran cenderung melakukan bertindak pada cara ia belajar atau metode belajar. Nilai rata-rata hasil belajar IPA siswa secara umum pada dimensi kesigapan belajar dan metode belajar berada pada kategori sedang. Secara lebih rinci kesigapan belajar dan metode belajar disajikan berdasarkan nilai per dimensi. Perbandingan nilai per dimensi kesigapan belajar dan metode belajar disajikan pada Tabel 2.

Tabel 2. Nilai Per Dimensi Kesigapan Belajar

\begin{tabular}{ccc}
\hline Dimensi Kesigapan Belajar & Nilai & Kategori \\
\hline Ketepatan waktu penyelesaian tugas & 65 & Baik \\
Konsentrasi belajar & 66 & Baik \\
\hline
\end{tabular}

Berdasarkan Tabel 2 nilai dimensi konsentrasi belajar dan ketepatan waktu penyelesaian tugas tidak jauh berbeda. Hal tersebut menunjukkan bahwa dalam kesigapan belajarnya, siswa cenderung pada dimensi konsentrasi belajar. Berdasarkan kategori nilai per dimensi kesigapan belajar berada pada kategori baik.

Tabel 3. Nilai Per Dimensi Metode Belajar

\begin{tabular}{ccc}
\hline Dimensi Kesigapan Belajar & Nilai & Kategori \\
\hline Prosedur belajar & 64 & Baik \\
Keterampilan belajar & 65 & Baik \\
Strategi belajar & 69 & Baik \\
\hline
\end{tabular}

Berdasarkan Tabel 3 perbandingan nilai antara dimensi prosedur belajar dan keterampilan belajar tidak jauh berbeda sementara itu, nilai dimensi strategi belajar lebih tinggi dibandingkan dimensi prosedur belajar dan keterampilan belajar. Hal tersebut menunjukkan bahwa metode belajar yang digunakan siswa cenderung pada dimensi strategi belajar. Kualifikasi metode belajar berdasarkan nilai per dimensi berada pada kategori baik.

Merujuk dari hasil uji asumsi klasik menunjukkan bahwa data terdistribusi normal, data linier, tidak terdapat gejala multikolinieritas, tidak terdapat autokorelasi dan tidak mengandung heteroskedastisitas. Setelah itu dilanjutkan dengan teknik analisis data dengan analisis korelasi dan regresi. Uji hipotesis penelitian dilakukan menggunakan analisis korelasi sederhana dan korelasi 
ganda serta regresi linier sederhana dan regresi ganda dua prediktor. Selain uji korelasi dan regresi juga dilakukan analisis untuk menentukan kontribusi berupa sumbangan efektif (SE) dan sumbangan relatif (SR) dari variabel kesigapan belajar dan metode belajar terhadap hasil belajar IPA. Ringkasan hasil analisis data secara lengkap disajikan pada Tabel 4.

\section{Tabel 4. Hasil Uji Hipotesis}

\begin{tabular}{lccccclll}
\hline \multicolumn{1}{c}{ Variabel } & Sig & $\mathrm{r}$ & $\mathrm{R}^{2}$ & $\mathrm{~F}_{\mathrm{h}}$ & $\mathrm{F}_{\mathrm{t}}$ & \multicolumn{1}{c}{ Persamaan Regresi } & $\mathrm{SE}(\%)$ & $\mathrm{SR}(\%)$ \\
\hline $\mathrm{X}_{1} \rightarrow \mathrm{Y}$ & 0,00 & 0,94 & 0,88 & 9,78 & 3,91 & $\hat{Y}=30,121+0,437 \mathrm{X}_{1}$ & 23,56 & 26,04 \\
$\mathrm{X}_{2} \rightarrow \mathrm{Y}$ & 0,00 & 0,95 & 0,90 & 11,8 & 3,91 & $\hat{Y}=29,275+0,449 \mathrm{X}_{2}$ & 66,94 & 73,96 \\
$\mathrm{X}_{1}$ dan $\mathrm{X}_{2} \rightarrow \mathrm{Y}$ & 0,00 & 0,95 & 0,90 & 6,03 & 3,07 & $\hat{Y}=29,040+0,246 \mathrm{X}_{1}+0,698 \mathrm{X}_{2}$ & 90,5 & 100 \\
\hline
\end{tabular}

\section{Pembahasan}

Hasil analisis pada penelitian ini menyatakan bahwa 1) terdapat korelasi yang positif dan signifikan antara kesigapan belajar dan hasil belajar IPA dengan sumbangan efektif (SE) sebesar $23,56 \%, 2$ ) terdapat korelasi yang positif dan signifikan antara metode belajar dan hasil belajar IPA dengan sumbangan efektif (SE) sebesar $66,94 \%, 3$ ) terdapat korelasi yang positif dan signifikan secara bersama-sama antara kesigapan belajar dan metode belajar dengan hasil belajar IPA siswa pada pembelajaran jarak jauh dengan sumbangan efektif (SE) sebesar 90,5\%.

Menurut Djaali (2009), hasil belajar dipengaruhi oleh faktor internal dan eksternal. Pada penelitian ini, kebiasaan belajar merupakan salah satu faktor internal yang mempengaruhi pencapaian hasil belajar siswa. Kesigapan dalam belajar dan metode kerja dalam belajar merupakan bagian dari kebiasaan belajar, melalui kesigapan dalam belajar dan metode kerja dalam belajar yang baik maka akan membentuk sebuah kebiasaan belajar yang baik pula. Pendapat lain oleh Sudjana (2014) menyatakan bahwa belajar bukan tentang lamanya tapi tentang kebiasaan yang teratur dan rutin melakukan belajar setiap harinya meskipun dengan jam terbatas. Hal ini mengartikan bahwa keberhasilan siswa dalam mengikuti pelajaran banyak bergantung pada kebiasaan teratur dan berkesinambungan.

Kesigapan belajar dan hasil belajar IPA secara umum menunjukkan korelasi yang bersifat positif. Artinya, jika kebiasaan belajar baik maka hasil belajar IPA yang dapat dicapai siswa juga akan mendapat hasil yang optimal. Hasil penelitian ini didukung oleh penelitian sebelumnya yang dilakukan Andrie et al., (2019) yang menyatakan bahwa secara parsial kebiasaan belajar pada variabel delay avoidan memiliki pengaruh signifikan terhadap prestasi belajar siswa. Kesigapan belajar memberikan kontribusi yang positif terhadap hasil belajar IPA sebab kesigapan belajar berkaitan dengan perilaku siswa dalam menyelesaikan tugas-tugas pelajaran secara tepat waktu, dan konsentrasi belajar. Siswa yang memiliki kebiasaan menyelesaikan tugas tepat waktu sebelum batas pengumpulan tidak hanya dapat meningkatkan hasil belajar namun juga potensi siswa, artinya siswa akan terus terlatih menindaklanjuti tugas-tugas sehingga dapat memiliki kemampuan dalam menyelesaikan tugas-tugas pelajaran yang baik.

Hal ini diperkuat oleh penelitian yang dilakukan Suryadi (2016) yang menemukan bahwa terdapat hubungan yang signifikan antara variabel kemampuan menyelesaikan tugas-tugas pelajaran dengan hasil belajar siswa. Hal ini mengindikasikan bahwa semakin baik kemampuan menyelesaikan tugas pelajaran oleh siswa semakin baik pula hasil belajarnya, sebaliknya semakin rendah kemampuan menyelesaikan tugas pelajaran oleh siswa semakin rendah juga pencapaian hasil belajarnya. Begitu pula dengan konsentrasi belajar yang juga berpengaruh besar terhadap hasil belajar siswa. Menurut Slameto (2010), siswa yang sudah terbiasa berkonsentrasi pada suatu hal akan dapat belajar dengan baik, kapanpun dan dimanapun. Artinya, kemampuan memusatkan perhatian atau konsentrasi saat belajar akan menentukan hasil belajarnya. 
Sementara itu, nilai konversi per dimensi dari variabel kesigapan belajar menunjukkan bahwa dimensi ketepatan waktu penyelesaian tugas-tugas pelajaran memiliki nilai terendah. Hasil temuan ini menunjukkan bahwa siswa belum mampu menindaklanjuti tugas-tugas yang diberikan oleh guru. Bagi guru pemberian tugas digunakan untuk mengetahui seberapa jauh kemampuan kognitif yang telah dimiliki siswa mengenai materi yang telah diajarkan. Sedangkan bagi siswa mengerjakan tugas adalah salah satu bagian dari belajar yang merupakan suatu kewajiban yang harus dilakukan.

Menurut Slameto (2005) agar siswa berhasil dalam belajar perlu mengerjakan tugas dengan sebaik mungkin, karena dengan menyelesaikan tugas tepat waktu akan mengurangi rasa cemas pada diri siswa. Tugas itu mencakup mengerjakan pekerjaan rumah (PR) baik berupa soal maupun makalah, menjawab soal latihan buatan sendiri, soal dalam buku paket pegangan siswa atau LKS, ulangan harian dan ulangan umum.

Suatu tugas dapat dikerjakan dengan baik dan dapat selesai tepat waktu apabila ditunjang oleh bahan atau materi yang diperlukan. Oleh karena itu, kegiatan pertama siswa dalam mengerjakan tugas adalah mempersiapkan bahan-bahan sesuai materi yang relevan. Kemudian dalam menyelesaikan tugas dengan tepat waktu, hal yang harus diperhatikan adalah mutu tugas dan waktu pengerjaan tugas. Untuk menyelesaikan tugas dengan mutu yang baik maka tugas tersebut perlu dikerjakan dengan waktu yang cukup, oleh karena itu perlu merencanakan waktu pengerjaan dan penyelesaian tugas (Prayitno, 2002). Setiap tugas yang diperoleh dalam setiap pembelajaran yang diikuti siswa tidak sekedar diselesaikan seadanya namun hendaknya dapat memenuhi kualitas atau mutu dari kriteria yang diharapkan disamping dapat diselesaikan dengan tepat waktu. Penundaan dalam mengerjakan tugas-tugas membuat tugas tersebut menjadi bertumpuk-tumpuk menjadi semakin banyak.

Metode belajar dan hasil belajar IPA secara umum berkorelasi positif dan signifikan. Hal tersebut berarti semakin baik metode kerja dalam belajar maka semakin baik pula hasil belajar siswa. Hasil penelitian ini didukung oleh penelitian yang dilakukan Andrie et al., (2019) yang menyatakan bahwa secara parsial kebiasaan belajar pada variabel work methods berpengaruh secara signifikan terhadap prestasi belajar siswa.

Metode belajar memberikan kontribusi yang positif terhadap hasil belajar IPA sebab metode belajar berkaitan dengan prosedur belajar atau cara-cara mengikuti pelajaran yang sudah disusun sesuai dengan keterampilan dan strategi belajar masing-masing. Sementara itu, nilai konversi per dimensi menunjukkan bahwa dimensi prosedur belajar pada metode belajar memiliki nilai yang paling rendah dibandingkan dimensi keterampilan dan strategi belajar. Hasil temuan ini menunjukkan bahwa rasa ingin mengikuti kegiatan belajar siswa rendah. Prosedur belajar merupakan kegiatan atau cara yang dilakukan sebagai upaya dalam memantapkan materi pelajaran yang diterima oleh siswa. Kegiatan tersebut berupa cara belajar di perpustakaan, cara membaca buku pelajaran, cara menggunakan internet untuk belajar, cara memperoleh materi pelajaran dan diskusi dengan teman.

Bagi siswa, prosedur belajar atau cara mengikuti pelajaran baik di sekolah maupun di luar sekolah merupakan bagian penting dalam kegiatan belajar. Siswa dituntut untuk menguasai bahan pelajaran apalagi saat ini pembelajaran menerapkan kurikulum 2013 yang menekankan pembelajaran berpusat pada siswa, artinya siswa harus aktif mengikuti kegiatan belajar. Dengan cara mengikuti pelajaran yang benar inilah siswa mendapat perubahan pengetahuan dan sikap atau kebiasaan yang baik saat melakukan belajar karena pada prosedur belajar terdapat cara mengikuti pelajaran di sekolah, cara belajar individu dan kelompok. Cara mengikuti pelajaran di sekolah merupakan bagian penting dari proses belajar sebab dalam proses belajar tersebut siswa diberikan arahan tentang apa dan bagaimana bahan pelajaran harus dikuasai. Sebelum mengikuti pelajaran siswa menyiapkan bahan-bahan pelajaran dan membaca materi yang akan dibelajarkan sebagai pengetahuan awal. Pembelajaran saat ini menekankan pembelajaran yang berorientasi pada siswa. Siswa saat mengikuti pelajaran aktif mendengarkan, bertanya dan menjawab soal, dengan aktif 
dalam mengikuti pelajaran siswa mudah memahami pelajaran. Apabila terbiasa melakukan hal tersebut maka akan membentuk kebiasaan belajar yang baik pada diri siswa.

Keterampilan belajar pada metode belajar berkaitan dengan keunikan cara belajar yang dilakukan oleh siswa dan metode ini membuat siswa lebih cepat dalam mempelajari suatu materi, kemampuan ini terlihat pada saat mempelajari hal-hal tertentu, seperti, membaca dan membuat catatan serta mengulang pelajaran untuk memudahkan mempelajari materi yang sulit. Membaca besar pengaruhnya terhadap belajar. Sebagian besar kegiatan belajar adalah membaca, sebab tujuan membaca adalah memahami bacaan yang dibaca, sehingga pemahaman merupakan faktor yang sangat penting dalam membaca. Setelah membaca buku pelajaran, siswa membuat catatan dengan mencatat hal-hal yang dianggap penting agar siswa mudah memahami dan mengingat materi yang dipelajari. Catatan yang tidak jelas, semrawut dan tidak teratur antara materi satu dengan materi lainnya akan menimbulkan rasa bosan dalam membaca, selanjutnya belajar jadi kacau. Sebaliknya catatan yang baik, rapi, lengkap, teratur akan menambah semangat dalam belajar. Dalam membuat catatan sebaiknya tidak semua yang dikatakan guru itu ditulis tetapi diambil inti sarinya saja. Mencatat materi pelajaran bisa juga dalam bentuk peta konsep untuk memudahkan memahami keterkaitan antar topik materi pelajaran. Kegiatan mengulang pelajaran untuk memudahkan mempelajari materi yang sulit. Mengulangi besar pengaruhnya dalam belajar, karena dengan mengulangi materi yang sulit dan belum dikuasai serta mudah terlupakan akan tetap tertanam dalam otak seseorang. Catatan yang sudah dibuat dapat digunakan untuk mengulang materi yang telah dipelajari dari catatan atau soal yang pernah dikerjakan.

Kemudian, strategi belajar pada metode belajar yang dimaksud berkaitan dengan metode yang digunakan untuk memperoleh hasil yang maksimal. Metode yang dimaksud adalah metode yang digunakan dalam mendekati suatu masalah, seperti menghadapi ujian. Situasi yang paling kritis dan mencemaskan dikalangan siswa adalah saat menghadapi ujian/tes. Kecemasan, kesibukan belajar mulai meningkat, sebaliknya istirahat dan perilaku santai mulai menurun. Singkatnya kesibukan belajar ditumpahkan pada saat itu, berbeda dengan hari-hari biasanya. Hal-hal tersebut dapat dihindari dengan membiasakan diri belajar teratur setiap saat. Siswa yang memiliki kebiasaan belajar yang baik pada saat akan menghadapi ujian akan dapat menyelesaikan soal-soal dengan tenang. Bila siswa telah memiliki catatan yang teratur, belajar telah teratur, soal-soal yang telah biasa dijawab dan dibaca, maka ujian adalah kesempatan menuangkan apa yang telah dikuasai. Sebab itu peristiwa ujian bukan ketegangan dan kekhawatiran tapi justru sebaliknya. Bukan kesibukan belajar yang meningkat malah sebaliknya, tinggal relaks membuka-buka pertanyaaan dan jawabannya yang selama kurun waktu telah dikerjakan secara teratur.

Hasil analisis data dalam penelitian ini menunjukkan bahwa kesigapan belajar dan metode belajar secara umum berada pada kategori baik, namun hasil belajar IPA berada pada kategori sedang. Dari kedua kebiasaan belajar tersebut didapatkan bahwa metode belajar memberikan kontribusi lebih besar terhadap hasil belajar IPA. Hal ini dikarenakan kegiatan-kegiatan pada metode belajar sering dilakukan siswa dalam pembelajaran sehingga mampu mendukung pencapaian hasil belajar kognitif dari jenjang paling rendah sampai paling tinggi, sebab metode belajar yang tepat memudahkan siswa dalam menerima dan memahami materi yang disampaikan.

Sesuai dengan kajian teori yang telah dipaparkan seharusnya apabila nilai kesigapan belajar dan metode belajar semakin baik, maka hasil belajar juga semakin baik. Hal ini menunjukkan kesenjangan kontribusi kedua prediktor terhadap kriterium dapat disebabkan oleh kontribusi variabel-variabel lain di luar penelitian ini. Hal tersebut juga didukung dengan hasil sumbangan efektif kedua prediktor terhadap variabel kriterium yaitu sebesar 90,5\%. Kesenjangan ini dapat disebabkan oleh beberapa faktor lain, seperti siswa cukup sulit memahami materi pembelajaran yang diajarkan secara online akibat adanya pandemi covid-19 sehingga siswa kesulitan mengerjakan tes yang diberikan, kelelahan, kebosanan dalam menjawab tes dan mengisi kuesioner serta adanya anggapan siswa bahwa hasil kuesioner dan tes tidak mempengaruhi nilai mereka di sekolah. 
Peneliti hanya dapat mengungkapkan satu faktor internal yang berkontribusi terhadap hasil belajar siswa yaitu kesigapan belajar dan metode belajar, padahal terdapat banyak unsur internal dan eksternal lainnya yang dapat memberikan kontribusi terhadap hasil belajar siswa, sehingga hal tersebut menjadi keterbatasan penelitian. Mengingat kedua jenis kebiasaan belajar tersebut sebagai faktor penting dalam pencapaian hasil belajar siswa, maka dilakukan penelitian lebih lanjut untuk mengetahui kontribusi kesigapan belajar dan metode belajar terhadap hasil belajar siswa pada pembelajaran jarak jauh.

\section{KESIMPULAN}

Hasil penelitian ini menunjukkan bahwa terdapat korelasi yang positif dan signifikan antara kesigapan belajar dan metode belajar secara simultan dengan hasil belajar IPA dengan angka signifikansi lebih kecil dari 0,05, koefisien korelasi sebesar 0,95 kategori sangat kuat, dan persamaan regresi yaitu $Y=29,040+0,246 X_{1}+0,698 X_{2}$. Kesigapan belajar dan metode belajar juga berkontribusi secara positif terhadap hasil belajar IPA dengan hasil sumbangan efektif (SE) kedua prediktor terhadap variabel kriterium yaitu sebesar $90,5 \%$.

Adapun saran yang dapat disampaikan sebagai tindak lanjut dari hasil penelitian ini yaitu, bagi peneliti selanjutnya supaya terlebih dahulu bereksplorasi di lapangan untuk dimungkinkan penambahan penggunaan variabel lain yang mungkin berkontribusi terhadap hasil belajar, baik dari faktor internal maupun eksternal.

\section{DAFTAR PUSTAKA}

Agustyaningrum, N., \& Suryantini, S. 2017. Hubungan Kebiasaan Belajar dan Kepercayaan Diri dengan Hasil Belajar Matematika Siswa Kelas VIII Smp N 27 Batam. JIPMat, 1(2):158-164.

Andrie, S., Novi, R.A., \& Saputri, D. 2019. Pengaruh Kebiasaan Belajar Terhadap Prestasi Belajar Siswa. Jurnal Pendidikan Ekonomi, 7(2):117-121.

Berutu, M. H. A., \& Tambunan, M. I. H. 2018. Pengaruh Minat dan Kebiasaan Belajar Terhadap Hasil Belajar Biologi Siswa SMA Se-Kota Stabat. Jurnal Biolokus, 1(2):109-116.

Candiasa, I. M. 2010. Pengujian Instrumen Penelitian disertai Aplikasi ITEMAN dan BIGSTEPS. Undiksha press

Depdiknas. 2003. Undang-Undang RI No 20 Tahun 2003. Tentang Sistem Pendidikan Nasional. Jakarta: Depdiknas.

Djaali, H. 2009. Psikologi Pendidikan. Jakarta: Bumi Aksara

Ebele, U. F., \& Olofu, P. A. (2017). Study Habit and its Impact on Secondary School Students Academic Performance in Biology in the Federal Capital Territory, Abuja. Educational Research and Reviews, 12(10): 583-588.

Gie, The Liang. (1995). Cara Belajar yang Efisien. Yogyakarta: Libert.

Gunawan, I. M. E., Murda, I. N., \& Margunayasa, I. G. 2019. Hubungan Kebiasaan Belajar dan Motivasi Berprestasi dengan Prestasi Belajar PKn. Media Komunikasi FPIPS, 17(1):1-10.

Jafari, H., Aghaei, A., \& Khatony, A. (2019). Relationship Between Study Habits and Academic Achievement in Students of Medical Sciences in Kermanshah-Iran. Advances in Medical Education and Practice, 10, 637-643.

Juliarta, B.P.I. 2013. Determinasi Motivasi Berprestasi, Kebiasaan Belajar, dan Kualitas Pengelolaan Pembelajaran Guru Terhadap Prestasi Belajar Praktik (Studi Persepsi Siswa Seni Rupa di SMKN 1 Sukawati). Tesis. Singaraja: Program Pasca Sarjana Universitas Pendidikan Ganesha

Kemendikbud. 2013. Lampiran Permendikbud Nomor 81A Tahun 2013 Tentang Implementasi Kurikulum Pedoman Umum Pembelajaran. Jakarta: Kementerian Pendidikan dan Kebudayaan RI. 
Napsawati. 2020. Analisis Situasi Pembelajaran IPA Fisika dengan Metode Daring di Tengah Wabah COVID-19 (Studi Kasus Peserta Didik MTS DDI Seppange Kabupaten Bone). Jurnal Pendidikan Fisika dan Terapannya, 3(1):6-12.

Narayana, I.W.G. 2016. Analisis Terhadap Hasil Penggunaan Metode Pembelajaran Synchronous dan Asynchronous. Semnasteknomedia Online, 4(1): 1-4-139.

Permendikbud 2018. Perubahan Atas Peraturan Menteri Pendidikan Dan Kebudayaan Nomor 37 Tahun 2018 Tentang Kompetensi Inti dan Kompetensi Dasar Pelajaran Pada Kurikulum 2013 Pada Pendidikan Dasar Dan Pendidikan Menengah.

Prayitno. 2002. Seri Latihan Keterampilan Belajar (program semu que IV). Padang: Depdiknas Purwanto, M. N. 2004. Psikologi Pendidikan. Bandung: Remaja Rosdakarya

Rosyida, F., Utaya, S., \& Budijanto, B. 2016. Pengaruh Kebiasaan Belajar dan Self-Efficacy terhadap Hasil Belajar Geografi di SMA. Jurnal Pendidikan Geografi, 21(2):17-28.

Rezaie Looyeh, H. Kazem Nejad Leili, E. 2017. The Relationship between the Study Habits and the Academic Performance of Medical Sciences Students. Journal of Holistic Nursing and Midwifery, 27(2), 65-73.

Saifullah, S., \& Muchlis, M. 2019. Hubungan antara Motivasi Berprestasi dan Kebiasaan Belajar Matematika Siswa dengan Prestasi Belajar Siswa. Supermat (Jurnal Pendidikan Matematika), 2(1):1-10.

Santyasa, I. W. 2014. Assesmen dan evaluasi pembelajaran fisika. Graha Ilmu.

Sinaga, L., Harahap, K. R. P., Sihaloho, C. A. P. Y., \& Bukhari, I. 2020. Analisis Strategi Pembelajaran Jarak Jauh Pada Materi IPA Selama Pandemi Covid-19 di Kota Medan. Jurnal Pendidikan Pembelajaran IPA Indonesia (JPPIPAI), 1(1):29-30

Slameto. 2010. Belajar dan Faktor-faktor yang Mempengaruhi. Jakarta: Rineka Cipta

Sudjana, N. 2005. Dasar-dasar Proses Belajar Mengajar. Bandung: Remaja Rosdakarya

Sugiyono. 2019. Metode Penelitian Kuantitatif, Kualitatif, dan R\&D. Bandung: Alfabeta

Suryadi, Erlamsyah, \& Yusri. 2016. Hubungan Kemampuan Menyelesaikan Tugas-tugas Pelajaran dengan Hasil Belajar Siswa. Jurnal Pendidikan Indonesia, 2(2):14-19.

Syah, M. 2009. Psikologi Belajar. Jakarta: Rajawali Pers

Widyantari, S. K. W., Suardana, I. N., Selamet, K. 2019. Pengaruh Strategi Belajar Kognitif, Metakognitif dan Sosial Afektif Terhadap Hasil Belajar IPA. Jurnal Pendidikan dan Pembelajaran Sains Indonesia, 2(2):151-160

Received, 23 Januari 2021

Accepted, 29 Maret 2021

\section{Elsa Octavia Sitohang}

Mahasiswa Program Studi S1 Pendidikan IPA FMIPA UNDIKSHA, aktif melakukan penelitian pada bidang Pendidikan IPA, dapat dihubungi melalui email: elsaosit@gmail.com.

\section{Nyoman Suardana}

Dosen Program Studi Pendidikan S1 IPA FMIPA UNDIKSHA, aktif melakukan penelitian pada bidang Pendidikan IPA, dapat dihubungi melalui email: inyomansuardana@gmail.com.

\section{Kompyang Selamet}

Dosen Program Studi S1 Pendidikan IPA FMIPA UNDIKSHA, aktif melakukan penelitian pada bidang Pendidikan IPA, dapat dihubungi melalui email: kompyangselamet@gmail.com. 